\section{Whaling dispute continues}

SIR - Apparently alarmed that an advertisement in Nature referencing the study of Baker and Palumbi (Science 265, 1538; 1994) might lend undeserved credence to the notion that illegal whale products find their way into Japanese markets, Milton Freeman (Nature 376, 11; 1995) reiterates the arguments of the Fisheries Agency of Japan (FAJ) that the study is fundamentally flawed. As Freeman's letter contains several serious errors, we feel obliged to comment.

First, Freeman states that "the meat of all species referred to by Baker and Palumbi could be legally imported into Japan until 1991". That is not true. The humpback whale was fully protected worldwide in 1966. To be legal, the humpback meat would have to have been stored for 30 years. At the meeting, one of us (R.L.B.) suggested an alternative explanation; the humpback meat came from a Japanese stranding or an incidental fishery kill that was processed because of the high value of whale meat.

Second, Freeman says that Baker and Palumbi were "seriously questioned" at a recent international symposium on marine mammal genetics; Freeman himself was not there. Two of us (A.E.D. \& W.F.P.) convened that symposium and Freeman is correct. The paper was seriously questioned - but only by N. Yagi of the FAJ. But the balance of the meeting participants accepted the methodology and results.

Third, Freeman misunderstands genetic methodology. Baker and Palumbi did not claim to find, as Freeman states, "an mtDNA sequence midway between a minke and a humpback".

Rather, two sequences were derived from amplification of two pieces of marinated meat from a single package; nothing was "midway". The authors' suggestion, that the product contained meat from two different sources, is entirely plausible. Freeman goes on to attribute, using quotation marks, the words "intermediate between a sperm whale and a harbour porpoise" to Baker and Palumbi, although this phrase does not appear in their paper. We trust this was a typographical error by Freeman and not an attempt to bolster his poor argument by incorrectly attributing a faintly absurd statement to the authors.

Our laboratory possesses a type sequence catalogue of all but 22 of the 80 or so extant cetacean species and we have extensive experience with intraspecific sequence variation in large datasets. Given a sequence of reasonable length, and ignoring rare interspecific hybridizaton in the wild of closely related species, we find (as do others) that identification to species of an unknown sample is a high-

Phillip J. Clapham ly practicable undertaking. With or without a complete collection of type specimens, mitochondrial DNA control region sequences easily discriminate between baleen and toothed whale samples. Sequences from different species do not "converge" upon one another. Thus Freeman's implication that the lack of type sequences for the toothed whales sold in Japanese markets could result in the incorrect identification of some baleen samples is entirely without foundation.

Andrew E. Dizon

William F. Perrin

Robert L. Brownell Jr

Southwest Fisheries Science Center,

National Marine Fisheries Service,

PO Box 271,

La Jolla, California 92038, USA

\section{ORI's unhappy lot}

SIR - John Maddox's account (Nature 376, 721; 1995) of the ORI/AAAS Conference on Plagiarism and Theft of Ideas was based on the ORI (Office of Research Integrity) report of the conference and misses the emotions at the event. Policemen were in the auditorium. At the time of the meeting, ORI was still concealing the fact that it would not prosecute supervisors for stealing ideas from their underlings. Jane Rosen made pointed comments from the floor about how her university and ORI had dealt with her case against her $\mathrm{PhD}$ supervisor.

Many in the audience were irritated to hear speakers talk of rules and procedures when it was obvious that cases were most often decided by political clout within the science community. I said from the floor that ORl's freedom of action was limited, and that the last two directors of its predecessor OSI lost their jobs after doing two vigorous investigations (of the Baltimore affair and the Gallo case). Lawrence Rhodes of ORI, on the podium, said I had insulted him. My remark and his response do not appear in the report.

The audience understood that the lot of ORI people is not a happy one. When I later said we should all thank them for being willing to "expose themselves to this angry mob" there was a roar of applause. My remark was altered in the report. "Angry mob" was omitted, leaving no reason for the applause, which was still mentioned. It may now be impossible to learn how much was changed between audiotape and report because ORI says it reused the tape and discarded the computer cassette transcribed from it.

\section{Charles W. McCutchen}

Camp Asulykit,

Lake Placid, New York 12946, USA

\section{No budget cuts}

SIR - I am surprised that you should have published (Nature 376, 718; 1995) a spurious story about alleged budget cuts based on a leaked letter from me. On 16 February 1995 I wrote to the research council chief executives advising them of figures to be used in future planning exercises. These figures were subsequently announced to parliament on 27 February in answer to a parliamentary question (Hansard, House of Commons Reports, Vol. 255, col 425, 27 February 1995).

These figures have therefore been in the public domain for more than six months and have been discussed already in the appropriate journals. There has been no secret about this, nor is it secret that it is the government's intention that all publicly funded research programmes should take account of the findings of the Technology Foresight exercise. The allocations of the Science Budget announced on 2 February for 1995-96 included some special initiatives designed to strengthen the science base in particular areas; the planning figures merely carried this forward. There is no justification for referring to these initiatives within the research council system as cuts to the science budget.

John Cadogan

(Director General of Research Councils)

Office of Science and Technology,

Albany House,

84-86 Petty France,

London SW1H 9ST, UK

\section{Factual errors}

SIR - In his review of my book The Price of Greatness: Resolving the Creativity and Madness Controversy (Nature 375, 547; 1995), Stuart Sutherland comments that my regression analysis correctly placed 95 per cent of my subjects and then says that 75 per cent could have been correctly placed on the basis of gender alone because "three times as many men as women were in the top quartile". This statement contains three factual inaccuracies. First, the analysis correctly placed 92 per cent of subjects, not 95 per cent. Second, three times the percentages of men as women - not three times as many - were in the top quartile. Third, gender alone does not accurately predict 75 per cent of the cases; it predicts only 63 per cent, about the same percentage as mental disturbances alone. Such careless errors are unexpected in a scholarly book review.

\section{Arnold M. Ludwig}

Department of Psychiatry,

University of Kentucky,

Lexington, Kentucky 40536-0080, USA

We regret the factual errors. - Editor, Nature. 